\title{
Proneofiber, a New Genus of Vole (Cricetidae: Rodentia) from the Pleistocene Seymour Formation of Texas, and its Evolutionary and Stratigraphic Significance
}

\author{
Claude W. Hibbard ${ }^{1}$ and Walter W. Dalquest ${ }^{2}$ \\ Received January 29, 1973
}

\begin{abstract}
A new genus and species of a microtine rodent, Proneofiber guildayi, is named on the basis of rooted teeth with cement from the warm Gilliland local fauna, Scymour Formation of Pleistocene age, Knox County, Texas. Proneofiber guildayi is considered to be ancestral to Neofiber, the round-tailed water rat, now living in the extreme southeastern United States. The presence of Pleistocene faunas prior to the first continental glaciation and the existence of three Pearlette-like volcanic ashes in the Plains Region suggest a revision of the age assignment of Pleistocene deposits from the nonglaciated region.
\end{abstract}

\section{INTRODUCTION}

Walter W. Dalquest collected, June 3, 1961, a partial skull, lower jaws and skeleton (No. V46174, Univ. Mich.) of a large vole with rooted teeth from a lens of red silty clay, just above the Permian, in the base of the Seymour Formation, approximately 2.75 miles south of Gilliland, Knox County, Texas. Hibbard and Dalquest (1966, p. 21, Fig. 4B-E) reported the specimen as Ondatra annectens (Brown). This identification was made on size, and rooted teeth. In November, 1972, Hibbard examined the dentition and discovered that it was not a specimen of Ondatra as previously reported.

The recognition of an ancestral form of the living water rat, Neofiber, as well as the knowledge that many of the Pleistocene deposits are older than the first continental glaciation, necessitates the reevaluation of

${ }^{1}$ Museum of Paleontology, The University of Michigan, Ann Arbor, Michigan 48104.

'Department of Biology, Midwestern University, Wichita Falls, Texas 76308. the age of the warm Gilliland local fauna from the Seymour Formation of Texas. This is supported by Zircon fission-track ages of three Pearlette-like volcanic ash beds in the Great Plains Region.

Taylor (1966) in evaluation of early Pleistocene Blancan nonmarine mollusks in the Great Plains considered a number of faunas to be older than the first continental glaciation of North America, during which the Nebraskan till was deposited, but younger than an episode of climatic cooling associated with alpine or limited continental glaciation. Hibbard (1970, p. 414), Flint (1971, Fig. 21-2), and Skinner et al. (1972) assigned the early Pleistocene warm local faunas to the interval prior to the first continental glaciation. Izett et al. (1970), Richmond (1970), Izett et al. (1971), Naeser et al. (1971), and Boellstorff (1972) have shown that three Pearlette-like volcanic ashes which are younger than the faunas considered to have lived prior to the first continental glaciation (Skinner et al., 1972) occur in Pleistocene deposits in the Plains Region. The occurrence of these 
three Pearlette-like ashes makes it possible to bracket the Gilliland local fauna.

\section{STRATIGRAPHY}

\section{Seymour Formation}

W. F. Cummins (1893, p. 181) described the Seymour Formation. The history of this formation is reviewed by Hibbard and Dalquest (1966) and a type location designated. It is evident that a hiatus exists between the silt and clay containing the Vera faunule (overlain by the type $O$ Pearlettelike ash) and the older beds containing the Gilliland local fauna which was taken from the Seymour Formation of Cummins.

The type O Pearlette-like ash (Izett et al., 1971 and Boellstorff 1972) occurs just above the unnamed silts containing the Cudahy fauna (an equivalent of the Vera faunule, Getz and Hibbard, 1965) in Knox County, Texas. The silts from which the Vera faunule was taken is no longer correlated with the Atwater Member of the Crooked Creek Formation of Meade County, Kansas (see Fig. 1).

At the time Hibbard (1949, Fig. 1) described the Crooked Creek Formation, it was believed that only one Pearlette volcanic ash existed. Therefore, the Borchers local fauna was shown above the Pearlette ash of the Crooked Creek Formation, and the Cudahy fauna below. The same error was made by Hibbard (1958, Fig. 1). No fauna has ever been recovered below the Pearlette-like (type B Borchers volcanic ash, which has been dated $1.9 \pm 0.2 \mathrm{~m} . \mathrm{y}$. (Naeser et al., 1971), and $2.379 \pm .418 \mathrm{~m} . \mathrm{y}$. (Boellstorff, 1972). The Borchers local fauna is just above a weathered zone on this ash. No type O, Pearlette-like ash, occurs in the type Crooked Creek Formation.

Hibbard and Dalquest (1966) thought the warm Gilliland local fauna from the Seymour Formation, Knox County, Texas, lived during a Kansan interstadial.

Our present interpretation of the warm Gilliland local fauna is that the sediments in which it occurs were laid down prior to Kansan glaciation. The fauna belongs to the Irvingtonian land-mammal age (Savage, 1951, p. 289). Nannippus phlegon (Hay), the little three-toed horse, and Equus (Dolichohippus) simplicidens (Cope), a zebrine horse, are known from the Stump Arroyo Member of the Crooked Creek Formation.

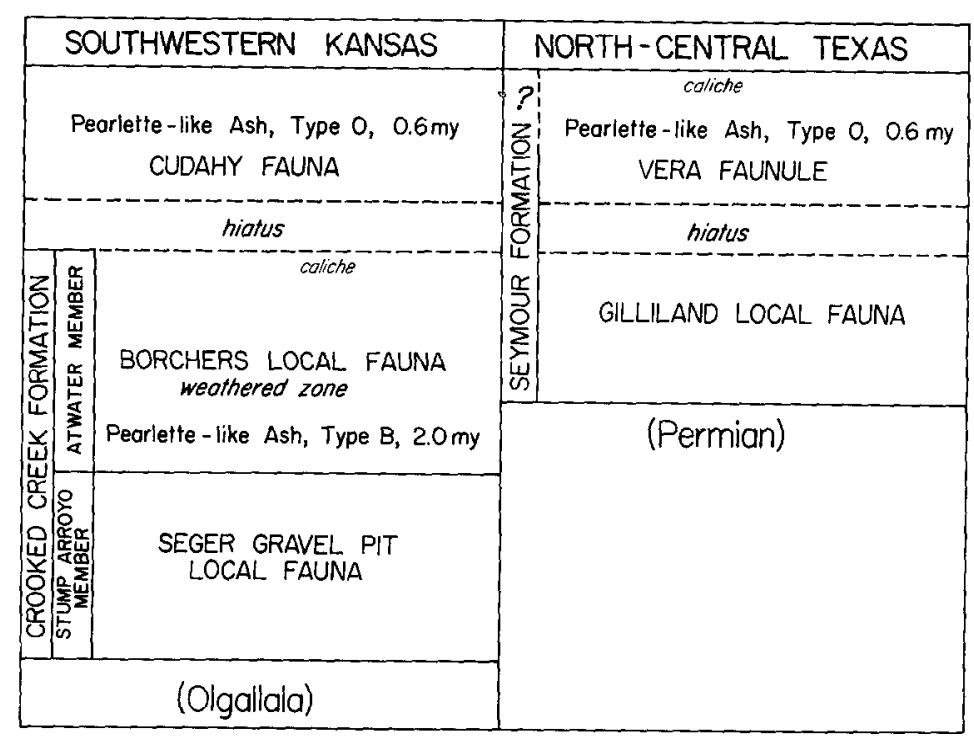

Fig. 1. The Crooked Creek Formation of Kansas and the Seymour Formation of Texas. Drawn by Stephen A. Hall. 
These horses have not been recovered above the Borchers ash (type B) in the Crooked Creek Formation.

At the present time, many of the known Pleistocene faunas from the nonglaciated regions cannot be assigned to the classical glacial-interglacial sequence of Central North America. Flint (1971, p. 543) stated, "The sequence recognizes only four major glaciations (some of them multiple) but no proof has been found that more than four did not occur."

If three million years are assigned to the Pleistocene duration based on radiometric dating, and the latest Kansan was only $600,000 \mathrm{yr}$ ago, the Nebraskan glaciation and its faunas are probably post-Blancan in age.

\section{FAMILY CRICETIDAE, SUBFAMILY ARVICOLINAE}

Proneofiber gen. nov.

Diagnosis. A vole approximately the size of Ondatra annectens (Brown) with welldeveloped cement (not interstitial cement) and rooted teeth in adults. The occlusal patterns of the upper and lower molars are similar to those of Neofiber. The salient angles (angular apices) of the alternating triangles have dentine tracts which produce an interrupted enamel pattern. The lower third molar has external reentrant angles with cement. The mental foramen is closer to the masseteric ridge than in Neofiber.

\section{Proneofiber guildayi $s p$. nov.}

Holotype. U.M.M.P. No. V46174, partial skeleton including part of skull, lower jaws with all teeth, left scapula, both humeri, left ulna, right tibia and fibula, both femurs, some foot bones, 13 caudal vertebrae and fragments. Taken June 3, 1961 by Walter W. Dalquest.

Type locality and horizon. Approximately 2.75 miles south of Gilliland, Knox County, Texas. From red silty clay near the base of the Scymour Formation.
Diagnosis. Same as for the genus.

Etymology. Proneofiber for its probable ancestral relationship to Neofiber; guildayi for John E. Guilday of the Carnegie Museum, who has contributed greatly to our knowledge of Pleistocene vertebrates of the Appalachian Highlands.

Description and discussion. The specimen is that of an adult with the temporal ridges fused in the orbital region. $\mathrm{M}^{1}$ consists of an anterior loop and four alternating triangles. The first two triangles are closed, the third opens into the fourth. An interrupted enamel pattern occurs except on the lingual side of the anterior loop (Fig. 2A and $\mathrm{B})$. The occlusal length of the tooth is $3.98 \mathrm{~mm}$; greatest occlusal width is 2.64 $\mathrm{mm}$. The greatest height of the posterior edge of the tooth is $8.5 \mathrm{~mm}$. The base is broken and it is not known if the anterior loop developed a root with one or two openings. The first lingual and first labial reentrant angles extend to the base of the tooth and are filled with cement. There is part of a posterior root that supported the last two triangles. Cement extends between

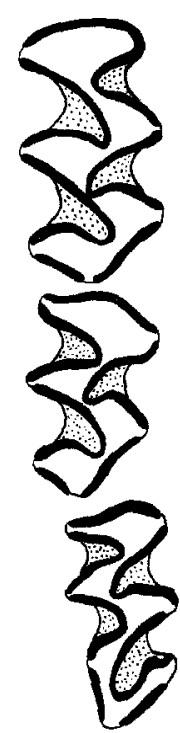

A
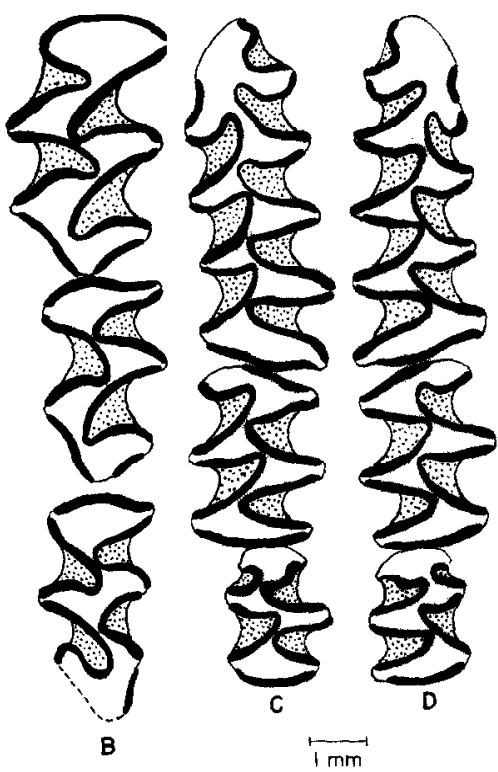

Fig. 2. A-D, V46174, Proneofiber guildayi gen. sp. nov., holotype, occlusal views of left and right upper molars (A and B) and lower molars (C and D). Drawn by Margaret $\mathbf{S}$. Stevens. 
2 and $3 \mathrm{~mm}$ high around the base of the tooth and completely fills the reentrant angles.

$\mathrm{M}^{2}$ consists of an anterior loop and three alternating triangles. Its occlusal length is $3.33 \mathrm{~mm}$, and greatest occlusal width is 2.24 $\mathrm{mm}$. The height of the anterior root and the loop it supports is $6.5 \mathrm{~mm}$. There is one large short root with two openings at the basc of the anterior loop, and a small root below the last (third) alternating triangle.

$\mathrm{M}^{3}$ consists of an anterior loop, two alternating triangles and a hook-shaped posterior loop. The occlusal length is $3.8 \mathrm{~mm}$, the greatest occlusal width is $1.9 \mathrm{~mm}$. The posterior height of the tooth is $5.0 \mathrm{~mm}$. The tooth has two roots. The anterior supports the anterior loop and first alternating triangle. The posterior root supports the posterior loop. In some very young Neofiber alleni True, the third alternating triangle of $\mathrm{M}^{3}$ has not opened into the posterior loop.

$\mathrm{M}_{1}$ consists of a posterior loop and five alternating triangles. The triangles are not as tightly closed as in Neofiber leonardi Hibbard (Midwestern Univ. No. 6794) or $N$. alleni. The reentrant angles are broader than in the two above species of Neofiber and also Ondatra annectens (U.M.M.P. No. V38334) from the Cudahy fauna of Meade County, Kansas. There are five internal reentrant angles. The anterior internal angle is located on the anterior loop and filled with cement. This angle containing cement is also present on M.U. No. 6794, an old adult. It is much deeper in Proneofiber guildayi than in Neofiber alleni. The occlusal length and width are 5.72 and $2.46 \mathrm{~mm}$. The roots are not exposed and it is assumed that two roots are present.

$\mathrm{M}_{2}$ consists of a posterior loop and four alternating triangles. The third and fourth are confluent. The fourth triangle has a wide interrupted enamel pattern on its anterolabial side. The occlusal length and width are 3.04 and $2.2 \mathrm{~mm}$. The roots are not exposed but it is assumed that only two roots are developed.
$\mathrm{M}_{3}$ consists of a posterior loop and three alternating triangles with two reentrant angles on both the labial and lingual sides. These reentrant angles are filled with cement. The occlusal length and width are 2.37 and $1.9 \mathrm{~mm}$. The two roots of $\mathrm{M}_{3}$ rest on the lingual side of the incisor. There is no capsular process developed on the lingual side of the jaw for the base of $M_{3}$ as in Neofiber leonardi and $N$. alleni.

The base of the incisor ends posterior to the dental foramen and does not develop a slight swelling on the labial side of the jaw as shown by M.U. No. 6794 in $N$. leonardi. The mental foramen is closer to the anterior end of the masseteric ridge than it is in Neofiber leonardi and $N$. alleni. The position of the mental foramen is more like that of Pliopotamys minor (Wilson).

Five lower third molars of Neofiber leonardi are known from the Kanopolis local fauna (Ellsworth County, Kansas, Ilolman, 1972). Four of these teeth have two labial reentrant angles. The other tooth has a single labial one and is like an adult of $N$. alleni. Nineteen lower third molars were examined from the Slaton local fauna (Lubbock County, Texas, Dalquest, 1967). Eighteen of the teeth had two labial reentrant angles. The other tooth is like an adult $N$. alleni. There are 16 specimens of Neofiber alleni in the collection of The University of Michigan Museum of Zoology. Nine of them are adult specimens and have an occlusal pattern of $\mathrm{M}_{3}$ as figured by Birkenholz (1972, Fig. 2). The other seven consist of two young adults and five immature specimens which have an $\mathrm{M}_{3}$ with two labial and two lingual reentrant angles. Two of the immature individuals have cement in the anterior labial reentrant angle. Birkenholz (1972) gives as part of the diagnosis of Neofiber alleni, " $\mathrm{M}_{3}$ with one outer fold." Ellerman (1941, vol. 2, p. 635) states, " $M_{3}$ reduced, with only one outer fold and two salient angles." These statements refer only to the occlusal pattern of $\mathrm{M}_{3}$ of adult specimens of Neofiber alleni. It is apparent that Hinton (1926, p. 92) 
had before him a young adult Neofiber. He states, " $M_{3}$ with three salient angles on each side."

The occurrence of Proneofiber guildayi in the Gilliland local fauna will furnish information on the rate of development of rootless teeth in Neofiber when the ages of the faunas in which the two genera occur are known. It is apparent that the genus $\mathrm{Neo-}$ fiber developed in North Amcrica. Agc and population variations of Proneofiber are unknown. The only stock known to us that might be ancestral to it is Pliophenacomys finneyi Hibbard and Zakrzewski (1972) from the Fox Canyon local fauna of Kansas. This form does not have the developed capsular process as does Ogmodontomys that lived with it. Furthermore, $P$. finneyi does possess higher dentine tracts than any known genus of microtine rodent from Upper Pliocene faunas, except P. primaevus Hibbard which occurs in a much later fauna.

The ancestral stock could not have been developed from the earliest Pliopotamys minor recovered from the Upper Pliocene Hagerman local fauna. A left lower jaw, U.M.M.P. No. V50213, taken at U.S.G.S Cenozoic series locality 20765 has the lower incisor extending well above the dental foramen and ending on the labial side in a small capsular process. This is characteristic of all complete lower jaws of Pliopotamys recovered from $350 \mathrm{ft}$ of deposits. The capsular process increases in size through time in this genus. The above jaw was taken $140 \mathrm{ft}$ below the level of KA 1173 (3.48 \pm 0.27 m.y.), Evernden, Savage, Curtis and James (1964). The length of the incisor varies within a genus as shown by Hibbard (1952 and 1963) in Synaptomys.

The warm Gilliland local fauna is postBlancan and pre-Cudahy fauna in age. We consider the fauna as pre-Kansan. The three local faunas from which Neofiber leonardi have been reported are here assigned to the Yarmouth. These include the Rezabek local fauna (Hibbard, 1943) considered as late Yarmouth, bccause it has slightly cooler faunal members than the Slaton (Dalquest, 1967) and the Kanopolis (Holman, 1972) local faunas. The Rezabek and the Kanopolis local faunas contain Ondatra annectens. No Ondatra is known from the Slaton local fauna. The Port Kennedy Cave local fauna that contains Ondatra hiatidens (Cope, 1899) and Neofiber diluvianus (Cope, 1899) is considered also as Yarmouth in age. Neofiber is considered as a southern form and Ondatra a northern form. They are found sympatric where the two distributions meet.

Note in proof: Boellstorff, J. D. (in letter, March 6, 1973) gave the Borchers ash (type B) as $1.97 \pm 0.25 \mathrm{~m} . \mathrm{y}$. , and stated "the dates published earlier were about $20 \%$ too old."

\section{ACKNOWLEDGMENTS}

We wish to express our gratitude to Emmet T. Hooper and Douglas M. Lay of the Division of Mammals of The University of Michigan Museum of Zoology, for permitting us free arcess to the collection of Recent mammals.

Figure 1 was drawn by Stephen A. Hall, Museum Assistant; Fig. 2 was drawn by Margaret, Skeels Stevens who was supported by N.S.F. Project G-19458. Mrs. Gladys Newton typed the manuscript.

\section{REFERENCES}

Birkenholz, D. E. (1972). Neofiber alleni, Mammalian Species, No. 15, 1-4.

BoetlstorfF, J. D. (1972). Fission track ages of shards from some mid-continent Pleistocene volcanic ash deposits. The Geological Society of America, Abstracts with Programs 4, (4), 274.

Cope, E. D. (1899). Vertebrate remains fiom Port Kennedy bone deposit. Journal Academy of Natural Sciences of Philadelphia 11, 193-267.

Cummins, W. F. (1893). Notes on the geology of northwest Texas. Texas Geological Survey, Fourth Annual Report (1892), 179-238.

Dalquest, W. W. (1967). Mammals of the Pleistocene Slaton local fauna of Texas. The southwestern Naturalist 12, 1-30.

Elderman, J. R. (1941). "The Families and Genera of living rodents: Vol. 2 (Family Muridae)," British Museum (Natural History), London.

Everndex, J. F., Savage, D. E., Curtis, G. H., AND James, G. T. (1964). Potassium-Argon dates and the Cenozoic mammalian chronology of North America. American Journal of Science 262, 145-198. 
Flint, R. F. (1971). "Glacial and Quaternary Geology." John Wiley and Sons, Inc., New York. Gexz, L. L., and Hibbard, C. W. (1965). A Molluscan faunule form the Seymour Formation of Baylor and Knox Countries, Texas. Papers of the Michigan Academy of Science, Arts, and Letters 50, 275-297.

Hrbbard, C. W. (1943). The Rezabek fauna, a new Pleistocene fauna from Lincoln County, Kansas. University of Kansas Science Bulletin 29 (Pt. 2), 235-247.

IIrbBard, C. W. (1949). Pleistocene stratigraphy and paleontology of Meade County, Kansas. Contributions from the Museum of Paleontology, University of Michigan 7 (4), 63-90.

HibBaRd, C. W. (1952). Vertebrate fossils from late Cenozoic deposits of Central Kansas. University of Kansas Paleontological Contributions, Vertebrata, art. 2, 1-14.

Hibbard, C. W. (1958). New stratigraphic names for early Pleistocene deposits in southwestern Kansas. American Journal of Science 256, 54-59.

Hibrard, C. W. (1963). A late Illinoian fauna from Kansas and its climatic significance. Papers of the Michigan Academy of Science, Arts, and Letters 48, 187-221.

Hibbard, C. W. (1970). Pleistocene mammalian local faunas from the Great Plains and Central Lowland Provinces of the United States. In "Pleistocene and Recent Environments of the Central Great Plains." (W. Dort, Jr. and J. K. Jones, Jr., Eds.), pp. 395-433. Department of Geology, University of Kansas Special Publication 3.

Hibbard, C. W., and Datquest, W. W. (1966). Fossils from the Seymour Formation of Knox and Baylor counties, Texas, and their bearing on the late Kansan climate of that region. Contributions from the Museum of Paleontology, University of Michigan 21, 1-66.

Hibbard, C. W., and Zakrzewski, R. J. (1972). A new species of $\mathrm{mi}$ rotine from the late Plio- cene of Kansas. Journal of Mammalogy 53, 834-839.

Hinton, M. A. C. (1926). "Monograph of the Voles and Lemmings (Microtinae) Living and Extinct." Vol. 1, British Museum (Natural History), London.

Holman, J. A. (1972). Herpetofauna of the Kanopolis local fauna (Pleistocene: Yarmouth) of Kansas. Michigan Academician 5 (1), 87-98.

IzeTt, G. A., Wilcox, R. E., Powers, H. A., AND Dresburough, G. A. (1970). The bishop ash bed, a Pleistocene marker bed in the western United States. Quaternary Research 1, 121-132.

IzetT, G. A., Wilcox, R. E., Obradovich, J. D., AND Rey nords, R. L. (1971). Evidence for two Pearlette-like ash beds in Nebraska and adjoining areas. Geological Society of America $A b$ stracts with Programs 3 (4), 265-266.

Naeser, C. W., IzetT, G. A., and Wilcox, R. E. (1971). Zircon fission-track ages of Pearlette-like volcanic ash beds in the Great Plains. Geological Society of America Abstracts with Programs, 3 (7), 657.

Richmond, G. M. (1970). Comparison of the Quaternary stratigraphy of the Alps and Rocky Mountains. Quaternary Research 1, 3-28.

Savage, D. E. (1951). Late Cenozoic vertebrates of the San Francisco Bay Region. University of California Publications, Bulletin of the Department of Geological Sciences 28 (10), 215-314.

Skinner, M .F., Hibbard, C. W., Gutentag, E. D., Smith, G. R., Lunderer, J. G., Holman, J. A., Feduccia, J. A, ANd Rich, P. V. (1972). Early Pleistocene Pre-glacial and Glacial rocks and faunas of north-central Nebraska. Bulletin of the American Museum of Natural History 148, 1-148.

TAYlor, D. W. (1966). Summary of North American Blancan nonmarine Mollusks. Malacologia 4 (1), 1-172. 